\title{
Drug Supply in the Penal System
}

B. Osmann (Boris Osmann), A Czirfusz (Attila Czirfusz)

SEUC PhD program in Health Management and Public Health, Pharmacist,

Magdeburg, DE.

\section{E-mail address:}

boris.osmann@sternapo.de

\section{Reprint address:}

Boris Osmann

SEUC PhD Program in Health Management and Public Health

Pharmacist

Heydeckstrasse 12

39104 Magdeburg

Germany

Source: Clinical Social Work and Health Intervention

Volume: 12

Issue: 3

Pages: $30-34$

Cited references: 15

\section{Reviewers:}

Andrea Shahum

University of North Carolina at Chapel Hill School of Medicine, USA

Steve Szydlowski

University of Scranton School of Education, USA

\section{Keywords:}

Drug Supply. Prisons. Health Risks. Treatment.

\section{Publisher:}

International Society of Applied Preventive Medicine i-gap

CSWHI 2021; 12(3): 30 - 34; DOI: 10.22359/cswhi_12_3_05 CC Clinical Social Work and Health Intervention

\section{Abstract:}

Common medical problems are normal in prisons, the quality of healthcare providers and the medication provided for prisoners has been a serious issue. Currently, the health policy has aimed to ensure that the National Health Services align with the prison health care services. ${ }^{1}$ The medication practices of the patients and the health care providers in the prisons are the ones that determine the extent to which they align with the National Health Services. ${ }^{2}$ This article focuses on

\footnotetext{
${ }^{1}$ Douglas C. Mc Donald, Medical Care in Prisons (1999) (https://www.journals.uchicago.edu/doi/abs/10. 1086/449301) accessed 3rd February 2021.

${ }^{2}$ Bowen, R.A., Rogers, A. \& Shaw, J. Medication management and practices in prison for people with mental health problems: a qualitative study. Int J Ment Health Syst 3, 24 (2009). https://doi.org/10.1186/17524458-3-24
} 
the main health problems that prisoners in correctional facilities; the forms of treatment supplied in the prisons; what factors influence the supply of drugs in prisons. We collected data from various articles and journals with information on this topic. We also compare the situation in different correctional facilities across Europe, mainly focusing on the drug supply in Germany. In particular, we seek to understand; the common health problems in correctional facilities; the forms of medication supplied for their treatment; how the drug supply can be improved.

\section{Introduction}

Research suggests that half the prisoners in Europe take part in substance abuse. It is one of the major problems facing penal systems today. The use of injections for the drugs has been an issue. Most communicable diseases such as HIV, Hepatitis $\mathrm{C}$ and Tuberculosis are more common in the prisons than the outside and these diseases are usually related to injecting drug use. Research provides that in Germany and other European countries the prevalence of TB was 1181 times greater than the usual; HPV was 17-100 times higher than usual; HIV was 5-24 times greater; opioid dependence prevalence had also increased in the correctional facilities. For communicable diseases such as TB, which is usually caused by close and prolonged contact. This explains why the prison setting facilitates its spread. $^{3}$

Many prisoners use injections as the main source of administering drugs. ${ }^{4}$ Drug use is the main problem affecting correctional facilities and it is probably the main cause of health care problems in the penal system. Common diseases such as HIV, Hepatitis B and C, and Tuberculosis are very high in correctional facilities as compared to the outside. ${ }^{5}$ Most of these are caused by the close and prolonged contact of the inmates and the common use of injections for administering illegal drugs. The use of injections for drug use can lead to the transmission of HIV and Hepatitis B and C.

Sexually transmitted diseases such as HIV and Hepatitis $\mathrm{C}$ can be transmitted by sexual contact as well as the unsafe use of injections and tattoo needles. Transmission risks are greater in correctional facilities due to the lack of sterilizing drugs and lack of protective sexual materials such as condoms. ${ }^{6}$

However, the prison systems provide a solution to this problem. They provide counseling, testing equipment, providing condoms, and sterilizing drugs to be used for injection material. They also initiates the substitution and methadone treatment for patients with opioid addiction. Different screening methods are used to identify infections in the prisons. In German prisons, systematic screening for infectious diseases has not been implemented. In Germany, effective health care treatment for HIV, hepatitis C and TB are given to patients with medical insurance. ${ }^{7}$ Nevertheless, according to the Prison Act. Healthcare in correctional facilities should take place with correspondence to the principle of equivalence of care and with the requirements stipulated in Statutory Health Insurance which provides that

\footnotetext{
${ }^{3}$ Heino Stoever \& Andrej Kastelic, Drug Treatment and Harm reduction prisons (January 2014) ((1) (PDF)

Drug treatment and harm reduction in prisons (researchgate.net)) accessed 3rd February 2021.

${ }^{4}$ D. Shewan, S. MacPherson, M. Reid \& Davies, Injecting risk behavior among recently released prisoners in Edinburgh: The impact of in-prison and community drug treatment services (2001)

${ }^{5}$ Tom Marshall, Sue Simpson \& Andrew Stevens, Healthcare in prisons: A healthcare needs assessment (15th October 2020).

${ }^{6}$ Müller et al. BMC Public Health (2017) 17:843

${ }^{7}$ Müller, J., Schmidt, D., Kollan, C. et al. High variability of TB, HIV, hepatitis C treatment and opioid substitution therapy among prisoners in Germany. BMC Public Health 17, 843 (2017). (https://doi.org/10.1186/s12889-017-4840-4) accessed 3rd February 2021.
} 
the healthcare measures taken in correctional facilities should correspond to those provided outside prisons. ${ }^{8}$ The treatment of prisoners getting outside and inside the prison should also be facilitated. Healthcare in the prisons is provided by the prison healthcare providers who are under the supervision of the prison administration who are both supervised by the Federal states.

\section{Tuberculosis Treatment}

Research conducted in Germany clearly shows how common TB is in the various penal institutions. ${ }^{9}$ In Saarland, it was observed that there was no medication supply of TB medication because TB isn't prevalent in the correctional facilities. In Bavaria, Berlin, and Thuringia, it was discovered that there was resistant and severe TB prevalence among the prisoners. Therefore, more medication has to be sent for the treatment. In Berlin, Bremen, and Hamburg, there has been high and continuous treatment in those correctional facilities. In Berlin, it has been observed that there's a high prevalence of TB in newly admitted prisoners. ${ }^{10}$ Most of the assessment tests are done using chest X-ray examinations. The treatment rates in Berlin are usually consistent with the TB prevalence in the penal institution. In Berlin, Bavaria, and Thuringia, prisoners are suffering from severe TB. Which was caused by the transfer of patients from one prison to the other. In Saarland, no treatments for TB are usually provided. Therefore, patients have to be transferred to other correctional facilities like Bavaria to receive treatment. This leads to increased transmission and severity of the disease.

\section{HIV Treatment}

Bremen, Hamburg, and Berlin have the highest treatment prevalences of HIV. Research provides that $\mathrm{HCV}$ is more common than HIV in the correctional facilities. ${ }^{11}$ The HIV treatment offered in the prisons is a combination of two Nucleoside reverse transcriptase inhibitors with NNRTI, PI or INI, which are used for the first therapy. Substances from standard therapy like the older NRTI- didanosine and the least common PI - Fosamprenavir, are usually administered. Sometimes newer substances are usually administered; however, the prison health care providers are usually hesitant to apply them. The new substance which is commonly used is the Rilprivin which is one of the substance group of the NNRTI. In the states of Bavaria, Hamburg, and Saarland, the continuous and recurrence of the disease of previously treated prisoners is usually common. ${ }^{12}$ Therefore, in such states, etravirine is supplied to counter this problem, to treat antiretroviral treatment-experienced patients.

\section{Hepatitis C Virus Treatment}

Research shows that only $0.12 \%$ of the prisoners with $\mathrm{HCV}$ are able to receive treatment in a day. ${ }^{13}$ The treatment supplies are too low con-

\footnotetext{
${ }^{8}$ K. Duke, Drugs, prison and policymaking (2003)

${ }^{9}$ Daniel E. Winetsky et al, Screening and Rapid Molecular Diagnosis of Tuberculosis in Prisons in Russia and Eastern Europe: A Cost-Effectiveness Analysis (November 27, 2012) accessed 3rd February 2021 (https://doi.org/10.1371/journal.pmed.1001348).

${ }^{10}$ Aerts. A, Hauer. B, Wanlin.M \& Veen. J, Tuberculosis and Tuberculosis control in European Prison (November 2006) P. 1215-1223.

${ }^{11}$ Michel Rotily, Caren Weilandt, Sheila M. Bird, Kerstin Kall, Harry J.A. Van Haastrecht, Emma Landolo, Sylvette Rousseau, Surveillance of HIV infection and related risk behavior in European prisons: A multicentre pilot study, European Journal of Public Health, Volume 11, Issue 3, September 2001, P 243 250, (https://doi.org/10.1093/eurpub/11.3.243) accessed 3rd February 2021.

${ }^{12}$ Golrokhi, R., Farhoudi, B., Taj, L., Pahlaviani, F. G., Mazaheri-Tehrani, E., Cossarizza, A., SeyedAlinaghi, S., Mohraz, M., \& Voltarelli, F. A. (2018). HIV Prevalence and Correlations in Prisons in Different Regions of the World: A Review Article. The open AIDS journal, 12, 81-92. (https://doi.org/10.2174/1874613601812010081) accessed 3rd February 2021.

${ }^{13}$ Arain, A., Robaeys, G. \& Stöver, H. Hepatitis C in European prisons: a call for an evidence- informed response. BMC Infect Dis 14, S17 (2014). (https://doi.org/10.1186/1471-2334-14-S6-S17) accessed 3rd February 2021.
} 
sidering that over $21 \%$ of the prisoners are infected with HCV. ${ }^{14}$ In Germany, Bremen is the only state with adequate medical supplies in correctional facilities for the treatment of $\mathrm{HCV}$; followed by Saarland and Schleswig-Holstein. Berlin and Hamburg have the lowest treatment prevalence. Berlin has the largest number of prisoners infected with HCV. It is, therefore, ironic that this is the state that has the lowest prevalence of treatment. However, the prevalence of HPV and its treatment are different in all the states' prisons, depending on the number of prisoners in the states infected with HCV, the number of Persons Who Inject Drugs (PWID) among prisoners, and the number of prisoners who are from countries where HCV is common. ${ }^{15}$ Studies have also shown $\mathrm{HCV}$ prevalence among prisoners is higher than HIV prevalence. However, the HCV medical supplies offered is much less as compared to the HIV medical supplies.

According to the recent guidelines, in prisons, $\mathrm{HCV}$ is treated by combining PEG-IFN and RBV. Sometimes they use a combination of three substances using one of the protease inhibitors BOC and TVR, combining it with PEG-IFN and RBV. This treatment is, however, very expensive and has a lot of side effects, therefore, very few correctional facilities use it. Other correctional facilities have chosen to use triple therapies containing BOC and TVR. States like Berlin, Bremen, Lower Saxony, and Saxony, have commonly used triple therapies for the treatment of HCV virus. In 2013, Direct Acting Antivirals (DAAs) were introduced but have not been released yet into the market for treatment. ${ }^{16}$ In Germany, the low prevalence of treatment may be re- lated to the long waiting for the upcoming treatments. Also, due to the side effects caused by the treatment, the prisoners are not willing to undergo the treatment. Moreover, the medication required for the treatment of HPV is costly.

\section{Opioid Dependence Treatment}

Substance abuse might lead to opioid dependency. It is usually associated with consequences such as HIV and Hepatitis B and C in prisoners because of using of non-sterilized injections. In Europe, an estimate of one-third of the total prisoners has an opioid disorder. Different forms of treatment are used for the treatment of opioid disorder. They include; substitution therapy (OST) and abstinence programs. Substitution therapy refers to the supervision of prescribed medical substance. $^{17}$

OST treatment was established for the people outside prison, however with time it was internationally endorsed by the UN and the World Health Organization,,$^{18}$ to be used in the prisons. ${ }^{19}$ OST is commonly used in the German correctional facilities; however, its implementation greatly depends on the rules and regulations provided by each state, the rules of the prisons and the health care providers in the various correctional facilities.

\section{Conclusion}

Substance abuse is the main cause of all the health issues experienced in correctional facilities. The government and the international rules have put in place strategies to ensure that the health care provided in the healthcare facilities is similar to the ones provided outside.

\footnotetext{
${ }^{14}$ Bielen, R., Stumo, S.R., Halford, R. et al. Harm reduction and viral hepatitis C in European prisons: a cross-sectional survey of 25 countries. Harm Reduct J 15, 25 (2018). (https://doi.org/10.1186/s12954-0180230-1) accessed 3rd February 2021.

${ }^{15}$ Francesco Negro, Epidemiology of Hepatitis C in Europe (15th December 2014) (pp. 158- 164) (https://doi.org/10.1016/j.dld.2014.09.023) accessed 3rd February 2021.

${ }^{16}$ Müller et al. BMC Public Health (2017) 17:843

${ }^{17}$ Stöver, H., Jamin, D., Michels, I.I. et al. Opioid substitution therapy for people living in German prisons inequality compared with the civic sector. Harm Reduct J 16, 72 (2019). (https://doi.org/10.1186/s12954019-0340-4) accessed 3rd February 2021.

${ }^{18}$ World Health Organization, 'Prison and Health' (Prisons and Health (who. int)) accessed 3rd February 2021.

${ }^{19}$ Heino Stoever, 'Drug Substitution treatment and needle exchange programs in Germany and European prisons' (2002)
} 


\section{References}

1. AERTS A, HAUER B, WANLIN M \&AMP; VEEN J (2006) Tuberculosis and Tuberculosis control in European Prison (November pp 1215-1223.

2. ARAIN A, ROBAEYS G \&AMP; STOVER $\mathrm{H}$ (2014) Hepatitis $C$ in European prisons: a call for anevidence-informed response. BMC Infect Dis 14, S17. (https://doi.org/10.1186/ 1471-2334-14-S6-S17) accessed 3 rd February 2021.

3. BIELEN R, STUMO S R, HALFORD R ET AL (2021) Harm reduction and viral hepatitis $C$ in European prisons: a cross-sectional survey of 25 countries. Harm Reduct J 15, 25 (2018). (https://doi.org/10.1186/s12954-0180230-1) accessed 3 rd February.

4. BOWEN R A, ROGERS A \&AMP; SHAW J (2021) Medication management and practices in prison for people with mental health problems: a qualitative study. Int J Mental Health Syst 3, 24 (2009). (https://doi.org/ 10.1186/ 1752-4458-3-24) accessed 3 rd February.

5. DOUGLAS C. MC DONALD (1999) Medical Care in Prisons (https://www.journals. uchicago.edu/doi/abs/10.1086/449301) accessed 3 rd February 2021.

6. SHEWAN D, MACPHERSON S, REID M \&AMP; DAVIES (2001) Injecting risk behavior among recently released prisoners in Edinburgh: The impact of in-prison and community drug treatment services.

7. NEGRO F (2014) Epidemiology of Hepatitis $C$ in Europe 15 th December. pp 158-164 (https://doi.org/10.1016/j.dld.2014.09.023) accessed 3 rd February 2021.

8. GOLROKHI R, FARHOUDI B, TAJ L, PAHLAVIANI F G, MAZAHERI-TEHRANI E, COSSARIZZA A, SEYEDALINAGHI S, MOHRAZ M, \&AMP; VOLTARELLI F A (2018) HIV Prevalence and Correlations in Prisons in Different Regions of the World: A Review Article. The open AIDS Journal, 12, pp 81-92. (https://doi.org/ $10.2174 / 1874613601812010081)$ accessed 3 rd February 2021.

9. STOEVER H \&AMP; KASTELIC A (2014) Drug Treatment and Harm reduction prisons (January 2014) ((1) (PDF) Drug treatment and harm reduction in prisons (researchgate. net)) accessed 3 rd February 2021.

10. STOEVER H (2002) Drug Substitution treatment and needle exchange programs in Germany and European prisons.

11. ROTILY M, WEILANDT C, BIRD S M, KALL K, VAN HAASTRECHT H J A, LANDOLO E, ROUSSEAU S (2001) Surveillance of HIV infection and related risk behavior in European prisons: A multicentre pilot study. European J of Public Health, Volume 11, Issue 3, September, pp 243250, (https://doi.org/10.1093/eurpub/11.3.243 ) accessed 3 rd February 2021.

12. MULLER et al. (2017) BMC Public Health $17: 843$

13. STOVER H, JAMIN D, MICHELS, I.I. ET AL. (2019) Opioid substitution therapy for people living in German prisons-inequality compared with the civic sector. Harm Reduct J 16, 72. (https://doi.org/10.1186/s12954019-0340-4) accessed 3 rd February 2021.

14. MARSHALL T, SIMPSON S \&AMP; STEVENS A (2020) Healthcare in prisons: A healthcare needs assessment 15 th October.

15. WORLD HEALTH ORGANIZATION (2021) Prison and Health (Prisons and Health (who. int)) accessed 3 rd February 2021. 